Riview scientific article

Received 17.05.2017.

Approved 29.08.2017.

\title{
BEYOND BUDGETING \\ - GAINING COMPETITIVE ADVANTAGE THROUGH STRATEGIC CHANGES IN BUDGETING PROCESSES
}

Process and leadership principles are the most important principles in every organization. Implementing or modifying new principles is mostly considered as a strategic change. However, there are some processes that have not been changed. Due to bureaucracy, conservative management and leadership principles, financial processes have been treated as universal without any needs for changing. Budgets have always played a big role in controlling the business performance of organizations. This paper emphasises the importance of making strategic changes in budgeting processes. Recently, budgets as the result of the budgeting process have become a subject of criticism. Budgeting as a concept of controlling has made businesses less flexible, even though nowadays flexibility is one of the most important factors which could determine the success of an organization. In a highly turbulent environment, traditional budgeting started being treated as a non-efficient way of controlling and running a business. This paper will summarize the reasons why companies all over the world start abandoning the concept of traditional budgeting and start implementing a new, more flexible concept, called Beyond Budgeting. Originally, the concept of Beyond Budgeting was implemented by Svenska Handelsbankena Swedish bank. This company has made an increase in almost every business process considering the relevant performance indicators. Beyond Budgeting modifies business processes and the need for a certain level of radical changes followed through the implementation of Beyond Budgeting principles. The author will point out which factors are possible limitations in using Beyond Budgeting. On the other hand, the author will show the necessary conditions which need to be fulfilled in order to implement Beyond Budgeting concept and get the benefits of using the business methodology.

Keywords: traditional budgeting, beyond budgeting, strategic change management, competitive advantage, flexible budgeting

Faculty of Organizational Sciences, University of Belgrade, Serbia radonic.milenko@gmail.com 


\section{Strategic changes and types of strategies for managing changes}

In a modern business environment, meeting market needs is necessary to achieve competitive advantage. Usually the improvement process is not visible from the outside, but from the inside, it generates an added value for all stakeholders. Hofer and Schendel (1978) define strategic changes as "changes in the content of a firm's strategy defined by its scope, resource deployments, competitive advantages, and synergy".

Strategic changes take time to be implemented, normally more than three months in SME and more than six months in bigger organizations. In the beginning, employees are sceptic about changes and do not see the potential effect on business performance and their satisfaction. It is normal for employees in the early stages of changes to refuse the organizational changes. However, it is important to be transparent during the presentation of strategic changes to the stakeholders (employees, management, vendors, clients), as well as the effects and importance of those changes. If stakeholders see the importance of it, it is more likely that they will understand and accept the change that will happen in the organization. ${ }^{2}$

How to know what to change? That is probably the hardest question for managers, since knowing what to change does not reassure the positive impact on business. It is important to mark that, there are some strategic changes that are more dangerous for business than others, so knowing the potential risk of a certain change is unavoidable. Flexibility is one of the key advantages companies could aim at. Some companies are more flexible than others due to different types of management, politics within the company and the industry. However, some processes depend less on the above-mentioned factors than others. Even though finance department and financial management are treated as a support in every business, they can either limit or boost the business performance.

Like every other change, changes in processes and leadership principles can generate employees' resistance. However, there are several strategies which could be used to manage a change in organizations.

Those types could be divided into four main categories:

- Empirical-Rational,

- Normative-Reductive,

- Power-Coercive,

- Environmental-Adaptive ${ }^{3}$.

Hofer Charles et al. (1978): Strategy formulation: Analytical concepts. St. Paul, MN: West, fn 12 Obradović Vladimir (2011): Capacity and design of organization for project change management. Serbian Project Management Journal, p. 42., fn 18

3 Chin Robert. et al. (1969): General Strategies for Effecting Changes in Human Systems. New York: Rinehard \& Winston., fn 8 
Empirical-Rational strategy treats people as rational beings, and communication is the key to accepting a certain strategic change. Normative-reductive strategy highlights the importance of organizational culture and the importance of corporate values. People are social beings and are willing to accept the corporate values. This strategy puts strategic changes in the terms of values and principles as a normal thing in business. The third strategy - Power-Coercive strategy believes that people like to be controlled and directed. More conservative management types use this strategy to implement changes. The last one assumes that people are adaptive and suggests building a new organization and moving people into it. There is not a single strategy that would fit the best for each situation, so management of a certain company has to combine several strategies.

The changes will affect profoundly both the management itself and the employees. It is crucial to identify two dimensions when implementing strategic changes. Those dimensions are time and scope. ${ }^{4}$

It is important to know what the strategic changes are, and could they be set as a baseline for the next period. Adoption of new targets and changes should be communicated on time so that employees could take time to accept a change.

Figure 1: Two dimensions of strategic changes for decision making

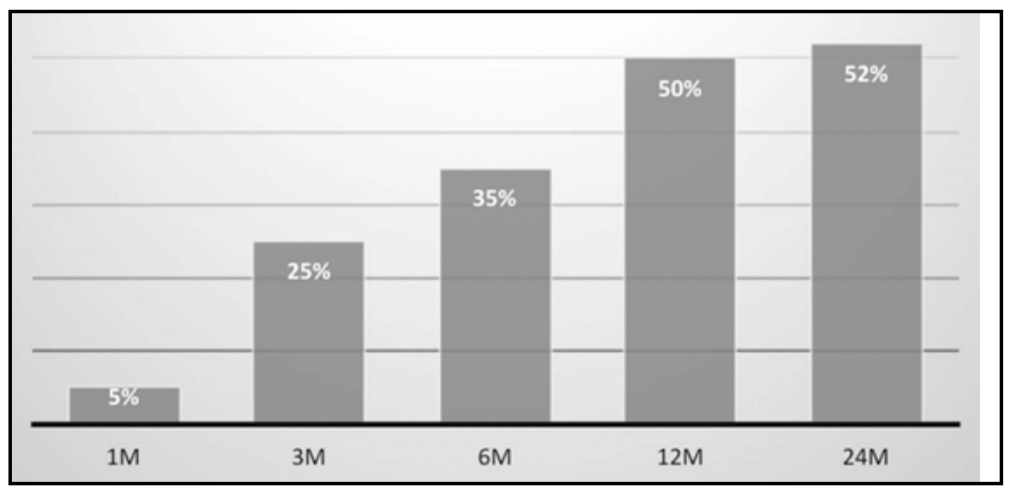

Like the Figure 1, management should reconsider the implementation of strategic changes through cost-effectiveness, by comparing time and scope of the change.

When choosing what time to pick for the implementation of a strategic change, it is important to have in mind three factors: the employee's resistance towards changes, the time needed for the implementation and the resources needed. Decision makers should also point out the estimated impact of changes in some departments or the whole organization.

$4 \quad$ Ali Naghibi M. et al. (2011): Strategic change management: The challenges faced by organizations. International Conference on Economics and Finance Research. 4, 543, fn 2 
Besides time and scope, capability and capacity are another two dimensions that should be included while deciding whether the company should implement some strategic change. Mostly considered capabilities are managerial and organizational capabilities, but individual capabilities are crucial as well.

Knowing what resource, the company needs to establish a strategic change is a part of a strategic plan. These are the facts that should be analysed before the change happens.

\section{Traditional budgeting and the reasons to abandon it}

Budgeting has always been present in human history. Business owners, managers, controllers need budgets to control the business and make decisions based on key performance indicators. However, today, many find limitations in the traditional budgeting. ${ }^{5}$

The purpose of this paper is to investigate the reasons for abandoning traditional budgeting and implementing Beyond Budgeting concept, as well as principles in the turbulent business environments. In recent years, consultants, managers and practitioners have proposed the abandonment of traditional budgets and the use of radically decentralized management models which refer to Beyond Budgeting. Traditional budgeting is considered as a tool for controlling the activities in most businesses.

Nowadays, many managers consider traditional budgeting as a limiting to their activities. That is why during the end of $20^{\text {th }}$ century it became the subject of criticism, considering the following:

- Budgets require a lot of time to be made and approved,

- Budgets limit responsiveness and flexibility,

- Budgets restrict changes,

- Budgets are rarely strategically focused and often contradictory,

- Budgets add little or no value,

- When making a budget, the focus is on cost reduction and not value creation,

- After budgets are made, they are mostly updated, and require the budget rebalance,

- Most of the budgets are supported by hypothesis and not by the facts,

- Budgets strengthen vertical command and control,

- Budgets do not reflect the emerging network structures that organizations are adopting,

- Budgets reinforce departmental barriers rather than knowledge sharing,

Abogun Segun (2011): The Global Debate on Budgeting: Empirical Evidence from Nigeria. International Business Research, 4, 248, fn 1 
- $\quad$ Budgets make people feel undervalued. ${ }^{6}$

The paper will show the examples of companies in strong economies such as in Scandinavian countries, US and Canada as well. Some of the Scandinavian companies were the first ones to abandon the traditional budgeting concepts. Later on, it became a trend for many companies in the US and Canada. The author has set a hypothesis which says that Beyond Budgeting principles could be implemented in different countries with the same effect due to market globalization.

According to the survey respondents done by Lisa Higgins (2005), employees treat traditional budgeting as: time-consuming and costly (72\%), not flexible, a process where it is hard and slow to detect problems and react (64\%) and it quickly becomes out of date $(49 \%)^{7}$

Despite the criticism of traditional budgeting process, nearly $87.8 \%$ of the companies have not abandoned and do not plan to abandon traditional budgets and ways of controlling the company's costs and activities. ${ }^{8}$

Many companies fail at implementing Beyond Budgeting, due to lack of organizational flexibility and considering that people having issues in accepting new changes.

From that point of view, it is important to identify the strategies that should be used as a part of the whole implementation process. Strategic changes could be identified according to the scope of change and nature of change as adoption, evolution, reconstruction, and revolution.

Figure 2: Types of Changes

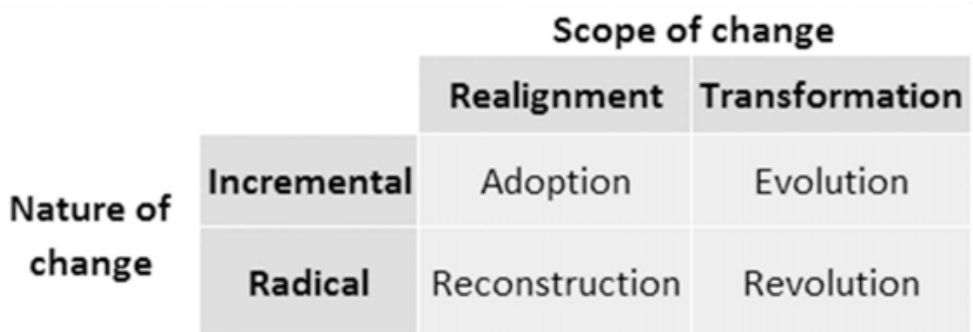

Source: Balogun J. and. Hope Hailey V. (1999)

$6 \quad$ Charted Institute of Management Accountants. (2004). Better Budgeting: A report on the Better Budgeting forum from CIMA and ICAEW. London: Charted Institute of Managemenet Accountants, 7, fn 7

7 Libby Theresa et al. (2010): Beyond budgeting or budgeting reconsidered? A survey of North-American budgeting practice. Management Accounting Research, fn 16

$8 \quad$ Ekholm Bo-Goran et al. (2010): Is the annual budget really dead? European Accounting Review, 9(4), 533, fn 9 
Beyond Budgeting could easily be found in several quadrants, which depend on the industry and current flexibility of a company. For start-up companies, it is more likely that the implementation of Beyond Budgeting could be considered as an adoption, but for corporations and other companies (with already built processes) this change could be considered as an evolution.

\section{Beyond Budgeting - the new concept of flexible budgeting}

Beyond Budgeting by Bogsnes (2009) is a new concept of budgeting made for more flexible environments which affect multiple aspects of the business. There are several publications which explain how Beyond Budgeting works. Authors of some of them are Bjarte Bogsnes (2009), Hope and Fraser (2003a), Bunce et al. (1995), Wallander (1999) and Morlidge and Player (2010). They all criticize traditional concepts of budgeting, including annual budgets as "fixed performance contracts". However, they suggest replacing this type of budgeting with more flexible and adaptive models of budgeting, budgeting techniques, rolling forecast, but also non-financial performance measures and other evaluations. Beyond Budgeting is still not that frequently used. There are still questions to be answered. ${ }^{9}$

The main question related to Beyond Budgeting is why companies fail at seeing a long-term benefit of using this type of budgeting, which is more efficient than the traditional budgeting. The structure of the companies, scope of business and ownership are just some of the factors which could be the obstacles to changing budgeting processes.

Beyond Budgeting requires strategic changes in the organization in the terms of improvement process (not just budgeting processes, but also the flow of information within the organization, job classification) and leadership processes. Therefore, there is an unanswered question: "Is Beyond Budgeting a universal concept to be adopted for every type of company in different environments?".

Considering that point, the main reasons why some companies are moving towards more flexible budgeting processes are the following:

- Traditional budgeting is too expensive and time - consuming;

- Traditional budgets tend to become fixed performance contracts in which the success rate is related to goal achievement;

- Traditional budgeting was initially made when the markets were more stable and less competitive. Hope and Fraser (2003) point out that organizations need to be as flexible as they can nowadays;

$9 \quad$ Niels Sandalgaard, et al. (2014): Beyond Budgeting and change: a case study. Journal of Accounting \& Organizational Change, 10(3), fn 17 
Bogsnes (2009) also argues that traditional budgeting includes more detailed and strict policy of tracking the costs which are pointless in turbulent business environments that are hard to predict. ${ }^{10}$ The comparison and critics of traditional budgeting could be found in Beyond Budgeting research.

Hope and Fraser (2003) include specific techniques, such as rolling forecast, relative performance evaluation, balanced scorecard and the creation of empowered teams. However, Borealis, the petrochemical firm used relative performance targets in order to benchmark with the industry performance. That is why in financial targets, it is useful to use vertical financial analysis in relative indicators. ${ }^{11}$

Relative performance targets which are proposed by BBRT as a part of Beyond Budgeting concepts may affect the universal applicability of the model. Hansen et al. (2003) points out that setting a relative target could show that many companies have a bad performance even though the absolute targets show differently ${ }^{12}$.

Scandinavian companies were the pioneers in establishing Beyond Budgeting principles and abandoning traditional ways. Svenska Handelsbanken was one of the first companies. Svenska Handelsbanken is a Swedish universal bank with revenues of around 2 billion dollars, 8,500 employees, and 600 profit centres (mostly branches). The rigid processes of traditional budgeting were seen as a limitation for improving business performances in this company. Svenska Handelsbanken has replaced the fixed annual budget by market-driven targeting, continuous monitoring, forecasting and resources allocation, as well as improving the customer support according to the continuous improvement.

Beyond Budgeting Round Table have made a list of companies which have implemented the Beyond Budgeting concept (see Table 1). They are valuable examples of other companies which plan to incorporate Beyond Budgeting.

By abandoning traditional budgeting, Svenska Handelsbanken has outperformed its competitors, considering many KPIs, such as ROE (return on equity), earnings per share, costs to income relative indicators, the rate of customer satisfaction, etc. Svenska Handelsbanken is the most cost-efficient bank in Europe and it was nominated to be one of the best Internet banks in Europe. ${ }^{13}$

Apart from Svenska Handelsbanken, Borealis A/S - a Danish company has also made an improvement in its budgeting system. It was established in 1994 as a joint venture between two Nordic oil companies (Statoil of Norway and Neste of Finland). Borealis is at the leading edge of polymer research and development and is now Europe's largest producer (sales of 2.5 billion dollars) and the fourth largest

$10 \quad$ Bogsnes Bjarte. (2009): Implementing Beyond Budgeting. John Wiley \& Sons, 16-17, fn 5

$11 \quad$ Hope Jeremy et al. (2003): Who Needs Budgets? Harvard Business Review, fn 13

12 Hansen Stephen et al. (2003): Practice Developments in Budgeting: An Overview and Research Perspective. Journal of Management Accounting Research, 95-116, fn 10

13 Hope Jeremy et al. (2003): Beyond Budgeting: How Managers Can Break Free from the Annual Performance Trap. Boston, Massachusetts: Harvard Business School Press, fn 11 
one worldwide. Beyond Budgeting has helped Borealis to react more flexibly to the market changes. Since it abandoned the budgeting model in 1995, Borealis has doubled its shareholder value and reduced costs by $30 \%$ over 5 years. The principles of Beyond Budgeting cannot be effectively implemented without paying special attention to the management information system. Most companies find this as a hardstrategic change. However, this change can radically improve business processes and performance rates of a company. Implementation of the system should support decentralized organizations with relevant information so that managers at all levels can use their intuition and judgment to make well-informed strategic decisions ${ }^{14}$.

Table 1: Companies which use Beyond Budgeting

\begin{tabular}{lll}
\hline Organization & Industry & Country of Origin \\
\hline Ahlsell & DIY Retail & Sweden \\
\hline American Express & Financial Services & USA \\
\hline $\begin{array}{l}\text { Beth Israel Deaconess } \\
\text { Medical Center }\end{array}$ & Health Care & USA \\
\hline ColoplastA & Medical products & Denmark \\
\hline dm drogerie-markt & Drug retail & Germany \\
\hline Egon Zehnder International & Executive recruitment & Switzerland \\
\hline W.L. Gore \& Associates & Multi-products manufacture & USA \\
\hline Google & Internet search & USA \\
\hline Guardian Industries & Float glass manufacture & USA \\
\hline Handelsbanken & Universal bank & Sweden \\
\hline HCL Technologies & IT Services & India \\
\hline Hilti & Building products & Liechtenstein \\
\hline John Lewis Partnership & Retail & UK \\
\hline Leyland Trucks & Truck manufacture & UK \\
\hline Nucor Steel & Steel maker & USA \\
\hline Southwest Airlines & Airline & USA \\
\hline Statoil & Oil \& Gas & Norway \\
\hline Sydney Water & Water utility & Australia \\
\hline Telekom Malaysia & Telecommunications & Malaysia \\
\hline Telenor & Telecommunications & Norway \\
\hline Toyota & Car manufacturer & Japan \\
\hline Whole Foods Market & Natural foods retailer & USA \\
\hline Source: Beyo Bus &
\end{tabular}

Source: Beyond Budgeting Round Table,

http://www.beyondbudgeting.org/beyond-budgeting/bbbbo.html $1^{15}$

\footnotetext{
14 AP AG. (2011): The White Paper: Beyond Budgeting. Walldorf: SAP AG, fn 22

15 The BBRT is the combination of a new concept ('beyond budgeting') and a community ('round table'). The BBRT community is an independent research collaborative that shares its knowledge across its global network through conferences and workshops.
} 
Svenska Handelsbanken and Borealis were one of the pioneers of Beyond Budgeting. After successful implementation of these principles, some other companies have started considering the implementation of the same model and concept. BBRT has made a list of the companies which have implemented Beyond Budgeting successfully.

Therefore, the first companies that rejected budgets were located in Northern Europe. However, the location, industries and cultures are the factors that do not represent limitations in implementing Beyond Budgeting principles.

\section{Beyond Budgeting principles}

Beyond Budgeting Model is made to overcome the limitations and weaknesses of traditional budgeting concept and help organizations achieve more by being more adaptive and flexible. That can be made by inside changes in key elements, such as the type of management, relationships, information flow etc.

Hope J. and Fraser R. as one of the founders of Beyond Budgeting as well as BBRT have made a list of principles that need to be established in order to adopt flexible budgeting.

Table 2: Leadership Principles

\begin{tabular}{ll}
\hline Customer & Focus on improving customer outcomes, not on hierarchical relationships. \\
\hline Organization & $\begin{array}{l}\text { Organize as a network of lean, accountable teams, not around centralized } \\
\text { functions. }\end{array}$ \\
\hline Responsibility & Enable everyone to act and think like a leader, not merely follow the plan \\
\hline Autonomy & Give teams the freedom and capability to act; do not micro-manage them. \\
\hline Values & $\begin{array}{l}\text { Govern through a few clear values, goals, and boundaries, not detailed rules and } \\
\text { budgets. }\end{array}$ \\
\hline Transparency & Promote open information for self-management; do not restrict it hierarchically. \\
\hline
\end{tabular}

Source: Bogsnes B. (2009), 23

Twelve principles which are proposed are made as a framework for implementing this model. Along with new tools and processes that could support the budgeting process in a better and more efficient way, there was also a need for establishing leadership principles. These principles are divided into two groups: six of them regarding leadership processes and the other six with process principles.

As described, principles 1 to 6 refers to performance management climate in companies. They involve both the design of the organization and the delegation of power and responsibility to people who are close to customers. 
Table 3: Process Principles

\begin{tabular}{ll}
\hline Goals & $\begin{array}{l}\text { Set relative goals for continuous improvement; do not negotiate fixed performance } \\
\text { contracts. }\end{array}$ \\
\hline Rewards & $\begin{array}{l}\text { Reward shared success based on relative performance, not on meeting fixed } \\
\text { targets. }\end{array}$ \\
\hline Planning & Make planning a continuous and inclusive process, not a top-down annual event \\
\hline Controls & Base controls on relative indicators and trends, not on variances against plan \\
\hline Resources & Make resources available as needed, not through annual budget allocations. \\
\hline Coordination & Coordinate interactions dynamically, not through annual planning cycles. \\
\hline
\end{tabular}

Source: Bogsnes B. (2009), 23

Principles from 7 to 12 refer to the processes of performance management. It is immensely important that goals, measures, and rewards are not tied together in a performance contract. The process principles point how the use of continuous (rolling) forecast can improve business performance. Setting goals, rewards, and controls are based on relative measures, in comparison to the competitors. The management of most of the companies mention leadership principles, but only small percentage really implement them with a strong coherence considering process principles as well. By Bjarte Bogsnes, Beyond Budgeting is a not a plan or "a recipe", but a philosophy that should be considered as a vision. ${ }^{16}$

Decisions in day-to-day business may change the course of direction or keep the same direction. Generally speaking, the process principles require a certain level of flexibility in order to make fast decisions. Rolling forecast helps management to estimate the outcome based on the current course. Overall, Bogsnes (2009) points out that leadership and process principles should fit the current business climate of continuous change ${ }^{17}$.

Rolling forecast needs to be adjusted to the ability of a company and its employees to change the perspective of motivation and management. Based on that, implementation of Beyond Budgeting includes moving the organization and its employees from theory $\mathrm{X}$ perspective to theory $\mathrm{Y}$ and from searching stability in organizations to being more flexible.

If a company is doing business in a dynamic environment, traditional, fixed budgets could limit business performances. However, due to the globalization of market, there are rare industries which are based in stable and not moving environments. In order to be competitive, companies are forced to engage their employees and move from centralization and micromanagement to decentralization, autonomy, transparency and internal motivation. Some of those factors are the main principles of Beyond Budgeting. The main concept of Beyond Budgeting stages is shown in Figure 3.

\footnotetext{
$16 \quad$ Bogsnes Bjarte (2009), 22-25, fn 5

17 Thomas Zeller et al. (2013): Good Bye Traditional Budgeting, Hello Rolling Forecast: Has the Time Come? American Journal of Business Education, 6(3), 299-310, fn 22
} 
Figure 3: Beyond Budgeting Matrix - Leadership and Processes Modification

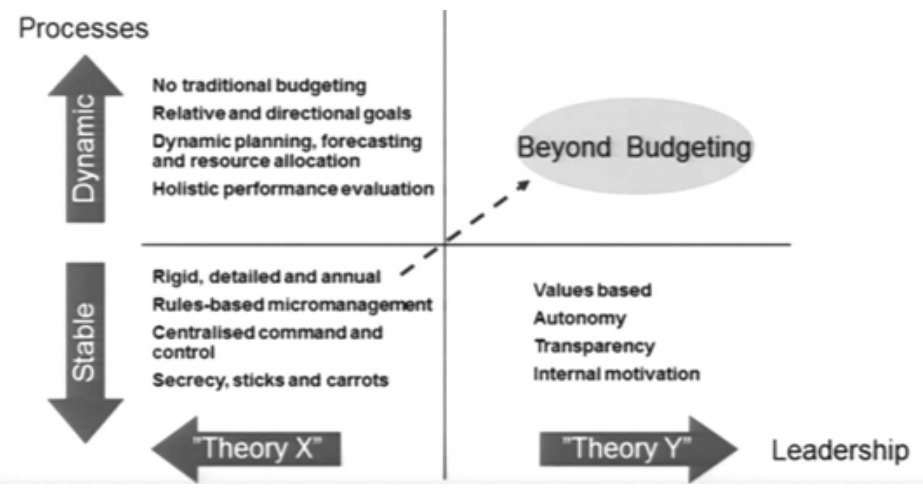

Source: Bogsnes B. (2009), 72

How did the mentioned companies implement BB? Instead of adopting fixed annual targets, business units set long-term goals which were based on internal and external benchmarks, considering key performance indicators such as ROE (Return on Equity), Debt-to-Equity, ROA (Return on Assets), etc. A company should set a few main long-term goals which will be focusing points for all activities. Borealis has set a goal defined by reducing fixed costs by $30 \$$ over five years and reducing the time lost to accidents in its plants. However, the company's business units and personnel are measured and rewarded according to the performance in reducing the costs and improving the uptime in comparison to best industry benchmarks.

Organizations have given the freedom to employees to make mistakes and fix them. On the other hand, managers have discretion in making decisions without big limitations in resources. They can obtain resources more quickly than in traditional organizations. In such systems, BB philosophy has a special meaning. Employees do not require much supervision, leaving more time for managers to act. Eliminating unnecessary activities, companies increase their flexibility and achieve more. $^{18}$

There are several factors which affect the possibility of implementing Beyond Budgeting model, such as the need for tracking non-financial measures, technology, and culture.

A lot of organizations find it difficult to link non-financial indicators to financial strategy and result. A Balanced scorecard is one of the tools to find the relationships between non-financial and financial KPI's. Finding the ways to improve and boost non-financial indicators is the first step. Setting the fixed plan in the terms of KPIs could also limit the financial results. Finding the right indicator to be tracked could be a hard task. It is important to distinguish key performance from key result and performance indicators. The difference between those types could be seen in Table 3 .

$18 \quad$ Hope Jeremy et al. (2003), 17, fn 13 
Table 4: 10/80/10 Rule

\begin{tabular}{ll}
\hline TYPE OF INDICATORS & GUIDANCE \\
\hline Key result indicators (10) & Give information how have organization done in perspective \\
\hline Performance indicators (80) & Give information and guidance what to do \\
\hline Key performance indicators (10) & Give information what to do to increase performance dramatically \\
\hline
\end{tabular}

Source: Permanter D, (2007), 9

A lot of organizations will probably track only $10 \mathrm{KPIs}$ restrictive and may wish to increase the number of KPIs. That could be acceptable and rational if an organization is made up from OF businesses from different sectors, in which case the 10/80/10 rule can be applied in each diverse business. Therefore, it is normal to increase KPI rollout. ${ }^{19}$

Beyond Budgeting concept proposes using more transparent and decentralized model to increase non-financial indicators as well.

The reason why budgeting process has improved during the period is that of the support of the technology and modern ERP systems. Technology has increased the speed and accuracy of budgets and has provided a possibility of forecasting. Working in a non-centralized system can cause many mistakes and not accurate numbers in budgets. Most of the businesses use Excel spreadsheets as the cheapest and most flexible option. When it comes to the integration of budgets, there is a slight chance of making a mistake. Centralized systems reduce that possibility and increase accuracy and speed. Beyond Budgeting requires flexibility and making changes in a budget according to the activities. Such model requires a centralized and fast system which can have an update frequently.

The third factor includes culture and incentives and it has the strongest influence on how formal systems operate. Fostering the right culture, whatever that may be in the context of individual companies was recognized as one of the most important factors. That is why culture takes a big part in the main Beyond Budgeting principles. ${ }^{20}$

19 Permanter David (2017): Key performance indicators - Developing, Implementing and Using Winning KPIs., 8-10, fn 19

20 Charted Institute of Managmenet Accountants. (2004), fn 7 


\section{The attitude towards abandoning traditional budgets as a controlling tool in the US and Canadian companies}

It is hard to predict how owners, managers and other employees would look at the process of implementation of Beyond Budgeting and its value. Even though it helps in improving business processes and increasing business performance, it requires a lot of discipline and flexibility at the same time.

In this paper, the result of the survey which was sent to the companies in North America and Canada will be considered. Out of 558 respondents, 212 were from US and 346 from Canada. Both, North America and Canada are considered as strong economies with a dynamic environment, but great possibilities.

Table 5: Descriptive statistics for survey respondents

\begin{tabular}{lccc} 
& Canada & US & $\begin{array}{c}\text { Combined } \\
\text { sample }\end{array}$ \\
Number of respondents & 346 & 212 & 558 \\
Mean years of employment: & & & \\
In current position & 4.4 years & 5.3 years & 4.8 years \\
With current company & 7.6 years & 8.6 years & 7.9 years \\
Job titles (frequency): & & & \\
Chief Financial Officer (CFO) & $30.00 \%$ & $22.00 \%$ & $26.60 \%$ \\
Managing executive & $5.20 \%$ & $5.10 \%$ & $5.20 \%$ \\
Business controller & $48.40 \%$ & $39.60 \%$ & $44.60 \%$ \\
Director of budgeting & $5.60 \%$ & $13.80 \%$ & $9.10 \%$ \\
Other & $10.80 \%$ & $19.50 \%$ & $14.50 \%$ \\
Economic sector (frequency): & & & \\
Manufacturing & $50.90 \%$ & $50.60 \%$ & $50.80 \%$ \\
Service & $49.10 \%$ & $49.40 \%$ & $49.20 \%$ \\
Corporate structure (frequency): & & & \\
Stand-alone unit & $46.60 \%$ & $44.10 \%$ & $45.50 \%$ \\
Division of a larger organization & $53.40 \%$ & $55.90 \%$ & $54.50 \%$ \\
\hline Business Unit Revenues (SIZE - frequency): & & & \\
Less than \$1 million & $5.40 \%$ & $1.90 \%$ & $3.80 \%$ \\
\$1-10 million & $21.00 \%$ & $12.60 \%$ & $17.10 \%$ \\
\$10-50 million & $34.40 \%$ & $28.30 \%$ & $31.60 \%$ \\
\$50-100 million & $16.10 \%$ & $13.60 \%$ & $14.50 \%$ \\
\$100-500 million & $14.50 \%$ & $22.60 \%$ & $18.30 \%$ \\
\$500 million - \$1 billion & $4.80 \%$ & $7.50 \%$ & $6.10 \%$ \\
\$1 billion - \$5 billion & $3.20 \%$ & $10.10 \%$ & $6.40 \%$ \\
Greater than \$5 billion & $60.00 \%$ & $4.30 \%$ & $2.20 \%$ \\
Mean Business Unit Revenues & $\$ 10-50$ million & $\$ 50-100$ million & \\
\hline & & & \\
\hline
\end{tabular}

Source: Libby Theresa et al. (2010), 59 
According to the survey done by Libby T. and Murray L. (2010), the average year of the employee working in a current company is 7.6 years in Canada and 5.3 years in the US and over $44.6 \%$ are working as a business controller and over $26.6 \%$ as CFOs. This survey was highly relevant since those positions are highly decision-making oriented regarding budgeting. The number of respondents in manufacturing industries is almost equal as in service-oriented industries.

Table 4 shows the structure of respondents, but in Table 5 there are the results and the attitude toward traditional and Beyond Budgeting and whether respondents would abandon traditional budgets.

Table 6: Use of budgets as a control too ${ }^{21}$

\begin{tabular}{lrrrrrr} 
& \multicolumn{2}{c}{ Canada } & \multicolumn{2}{c}{ US } & \multicolumn{3}{c}{ Combined sample } \\
\cline { 2 - 7 } & Freq & \multicolumn{1}{c}{$\%$} & Freq & $\%$ & Freq & $\%$ \\
Are budgets used for control? & & & & & & \\
Yes & 227 & $80.00 \%$ & 163 & $77.00 \%$ & 440 & $79.00 \%$ \\
No & 69 & $20.00 \%$ & 49 & $23.00 \%$ & 118 & $21.00 \%$ \\
Total & 346 & $100.00 \%$ & 212 & $100.00 \%$ & 558 & $100.00 \%$ \\
If budget is used for control: & & & & & & \\
$\begin{array}{l}\text { Do you plan to abandon the } \\
\text { use of budgets for control? }\end{array}$ & & & & & & \\
Yes & 2 & $1.00 \%$ & 2 & $1.00 \%$ & 4 & $1.00 \%$ \\
Possibly & 18 & $6.00 \%$ & 4 & $2.00 \%$ & 22 & $5.00 \%$ \\
No & 257 & $93.00 \%$ & 157 & $97.00 \%$ & 414 & $94.00 \%$ \\
Total & 277 & $100.00 \%$ & 163 & $100.00 \%$ & 440 & $100.00 \%$ \\
\hline
\end{tabular}

Source: Libby Theresa et al. (2010), 60

The results have shown that almost $80 \%$ of respondents consider budget as a tracking tool and a tool for controlling costs and activities. Due to that point of view, $94 \%$ of respondents do not think about abandoning budgets as a controlling tool.

Beyond Budgeting is a philosophy. Most of the companies still do not completely trust those principles. Many of the companies who have tried this method have achieved a great result. However, it requires radical changes which go from the top to bottom; from owners and management to employees.

Due to market globalization, there is a hypothesis that in countries with multinational companies, those organizations would have the same opinion. Consequently, there are not many companies willing to take that step.

In extreme cases, the use of budget to force performance improvements may lead to a breakdown in corporate ethics. People who worked at World

21 Control was defined as "the use of budgets for managerial motivation and as a standard for performance evaluation purposes". 
Com according to CEO Bernard Ebber were guided strictly by the annual and monthly budgets. World Com, Enron, Barings Bank, and other failed companies had tight budgetary control processes that conveyed information only to those who "need to know"22.

The success of the implementation of Beyond Budgeting can be determined according to few results, such as:

1. Time saved for people involved in budgeting process;

2. Saved costs;

3. Employee/Customer satisfaction rate;

4. Revenue growth.

Since budgeting is time-consuming, that is the first problem everyone gets frustrated with. By using Beyond Budgeting, some companies like Borealis and Handelsbanken have saved more than a few months yearly by implementing more flexible way. Budgets make a forecast of costs and most of the time people spend planned amount of money only because some cost is budgeted. In Beyond Budgeting, it is treated as a waste, so using the money to cover some costs has to be reasonable and have a purpose. With time-saving and providing more time for analysis and thinking, employees' satisfaction rate has increased dramatically in Borealis and Handelsbanken. ${ }^{23}$ All the mentioned benefits should provide more flexibility to the company and employees, so acting fast and using every business potential and possible opportunities are additional benefits which will affect revenue growth. With those of KPI's, strategic changes could be determined as successful.

\section{Conclusion}

Strategic change is a necessary part of modern businesses. In order to gain competitive advantage, organizations sometimes must implement radical changes. Knowing which strategy to use during the change adaptation is a key factor for the success of a company. The success of a certain change could be determined by measuring its result and comparing with the previous period. The issues that can be discussed are: the cost efficiency after the change, revenue growth, customers' or employees' satisfaction rate, etc. Financial processes and budgeting have been automatized through the years, but the core has not been modified for years. Many companies are afraid of those changes but knowing that their possible effect could provide a competitive advantage to a company could help companies get closer to Beyond Budgeting which is the treated as a strategic change. Budgets are considered as one of the most important tools in

\footnotetext{
$22 \quad$ Hope Jeremy et al. (2003), 110-115, fn 14

23 Bogsnes Bjarte (2009), 37, fn 5
} 
controlling. Based on various surveys and research, there is a small percentage of companies and management willing to abandon budgets and the concept of traditional budgeting as a limitation for process and performance improvement. In the history of Beyond Budgeting, there have been several successful examples of abandoning traditional budgeting and implementing more flexible - Beyond Budgeting concept which has increased the business performance metrics of those companies. The examples of Svenska Handelsbanken and Borealis have shown that even bigger corporations could be more adaptive and change according to the needs of the market much faster. However, it requires adequate strategic changes which include leadership and processes principles of the company. Based on the survey, $94 \%$ of respondents do not plan to abandon budgets as a tool in traditional budgeting. The paper emphasises that even though there are successful examples of Beyond Budgeting concept and the positive impact of it, there is a small percentage of stakeholders related to budgeting, which are ready to make strategic changes in order to implement Beyond Budgeting.

\section{Literature}

- Abogun, S., \& Olamide Fagbemi, T. (2011): The Global Debate on Budgeting: Empirical Evidence from Nigeria. International Business Research, 4, 248-254.

- Ali Naghibi, M., \& Baban, H. (2011): Strategic change management: The challenges faced by organizations. International Conference on Economics and Finance Research. 4, pp. 542-544. Singapore: IACSIT Press.

- Balogun, J., \& Hope Hailey, V. (1999): Exploring Strategic Change. Edinburgh: Prentice Hall.

- Beyond Budgeting Round Table, www.bbrt.org, 20.04.2017.

- Bogsnes, B. (2009): Implementing Beyond Budgeting. John Wiley \& Sons.

- Bo-Göran E., J. W. (2010): Is Annual Budget Really Dead? European Accounting Review, 4, 519-539.

- Charted Institute of Management Accountants. (2004): Better Budgeting: $A$ report on the Better Budgeting forum from CIMA and ICAEW. London: Charted Institute of Managmenet Accountants.

- Chin, R., \& Benne, K. D. (1969): General Strategies for Effecting Changes in Human Systems. New York: Rinehard \& Winston.

- Ekholm, B. and Wallin, J. (2010): Is the annual budget really dead? European Accounting Review, 9(4), 519-539.

- Hansen, S. C., Otley, D. T., \& Stede, W. A. (2003): Practice Developments in Budgeting: An Overview and Research Perspective. Journal of Management Accounting Research, 95-116. 
- Hope J., Fraser. R. (2003): Beyond Budgeting: How Managers Can Break Free from the Annual Performance Trap. Boston: Harward Business School Press.

- Hofer, C. Schender D. (1978): Strategy formulation: Analytical concepts. St. Paul, MN: West.

- Hope, J., \& Fraser, R. (2003): Who Needs Budgets? Harvard Business Review.

- Higgins, L. (2005): Leaders of the Pack: Practices That Streamline Financial Processes. Business Performance Management, 19-22.

- Husseini, S. E. (2015): EDLP versus Hi-Lo Pricing Strategies in Retailing. Otto Beisheim School of Management.

- $\quad$ Libby, T., Lindsay, M. (2010): Beyond budgeting or budgeting reconsidered? A survey of North-American budgeting practice. Management Accounting Research, 56-75.

- Niels S, Bukh P. N. (2014): Beyond Budgeting and change: a case study. Journal of Accounting \& Organizational Change, 10(3), 409-423.

- Obradović, V. (2011): Capacity and design of organization for project change management. Serbian Project Management Journal, 41-53.

- Permanter, D. (2017): Key performance indicators - Developing, Implementing and Using Winning KPIs.

- Pietrzak, Z. (2013): Traditional versus Activity-based Budgeting in Nonmanufacturing Companies. Social Sciences, 4, 26-37. doi:http://dx.doi. org/10.5755/j01.ss.82.4.6604

- Price Water House Coopers. (2014): Guide to Key Performance Indicators, 8-11.

- $\quad$ SAP AG. (2011): The White Paper: Beyond Budgeting. Walldorf: SAP AG.

- Thomas L. Zeller, L. M. (2013): Good Bye Traditional Budgeting, Hello Rolling Forecast: Has the Time Come? American Journal of Business Education, 6(3), 299-310. 
Pregledni naučni rad

Primljen 17.05.2017.

Odobren 29.08.2017.

\section{BEYOND BUDGETING \\ - STICANJE KONKURENTSKE PREDNOSTI KROZ STRATEŠKE PROMENE U PROCESU BUDŽETIRANJA}

Principi procesa i liderstva su jedni od najbitnijih unutar svake organizacije. Promena ili implementacija novih principa se najčešće tretiraju kao strateške promene. Svakako, postoje određeni procesi koju nisu mnogo menjani. Zbog birokratije i konzervativnog menadžmenta, finansijski procesi su često tretirani kao status kvo. Budžeti su uvek igrali veliku ulogu u kontrolingu poslovnih performansi. Ovaj rad ističe bitnost izmena procesa budžetiranja kroz sprovođenje strateških promena. Nedavno, budžeti kao product procesa budžetiranja su postali predmet kritike. Oni su kroz vreme učinili da organizacije i samo poslovanje budu manje fleksibilne, iako je danas fleksibilnost jedna od ključnih determinanti uspeha poslovanja jedne organizacije. U uslovima turbulentnog poslovanja, tradicionalni koncept budžetiranja postaje sve neefikasniji način rada kroz kontroling i usmeravanje poslovanja. Rad sumira razloge zašto su određene kompanije širom sveta krenule da napuštaju tradicionalni način budžetiranja i krenule u implementaciju novog koncepta, tzv. Beyond Budgeting. Originalno, Beyond Budgeting, je inicijalno implementran od strane švedske banke Svenska Handelsbanken. Beyond Budgeing predstavlja modifikovanje Kroz implementaciju ovakvog koncepta $i$ usvajanje Beyond Budgeting principa, pobošljani su mnogobrojni indikatori performansi, što je utvrdeno na primerima iz prakse. Autor u radu ističe koji faktori mogu limitirati mogućnost implementacije Beyond Budgeting principa, ali i uslove implementacije novog sistema budžetiranja, kao i benefite korišćenja ovakve biznis filozofije.

Ključne reči: tradicionalno budžetiranje, beyond budgeting, upravljanje srateškim promenama, konkurentska prednost, fleksibilno budžetiranje 